\title{
Arterial blood gas analysis or oxygen saturation in the assessment of acute asthma?
}

\author{
D M Carruthers, B D W Harrison
}

\begin{abstract}
Background - A study was undertaken to determine if arterial blood gas estimation is always necessary in the assessment of patients presenting to hospital with acute severe asthma, or whether oxygen saturation as measured by pulse oximetry is a reliable screening test for predicting those in respiratory failure.

Methods - A prospective study was conducted in a specialist respiratory medical unit. Arterial blood gas tensions and pulse oximetry were measured in 89 consecutive patients admitted with acute severe asthma. Respiratory failure was defined as $\mathrm{PaO}_{2}<8 \cdot 0 \mathrm{kPa}$ or $\mathrm{PaCO}_{2}>6 \mathrm{kPa}$.

Results - When oxygen saturation was $92 \%$ or higher (72 patients) respiratory failure was found in three $(4 \cdot 2 \%)$ cases. In the 82 patients with a saturation of $90 \%$ or higher six patients $(7 \cdot 3 \%)$ had respiratory failure. Conclusions - In the initial assessment of acute severe asthma an oxygen saturation of $>\mathbf{9 2} \%$ suggests that respiratory failure is unlikely and therefore arterial blood gas measurement is unnecessary. This study is only relevant to the assessment of asthmatic patients at presentation. Other parameters of severity must be continually assessed in all asthmatic patients admitted to hospital irrespective of the initial $\mathrm{SaO}_{2}$, and blood gases measured when clinically indicated.
\end{abstract}

(Thorax 1995;50:186-188)

Keywords: asthma, oximetry, arterial gases.

Hypoxia is a universal finding in acute exacerbations of asthma but respiratory failure with an arterial oxygen tension $\left(\mathrm{PaO}_{2}\right)$ below $8 \mathrm{kPa}$ or a raised arterial carbon dioxide tension $\left(\mathrm{PaCO}_{2}\right)$ above $6 \mathrm{kPa}$ occurs in no more than a third of patients. ${ }^{12}$ Cyanosis is a late sign of respiratory failure in severe asthma and indicates a very severe life threatening attack. ${ }^{3}$ Clinical features of less pronounced respiratory failure are unreliable and therefore guidelines recommend that arterial blood gas tensions should be measured on all patients presenting to hospital with acute severe asthma. ${ }^{3}$

Arterial puncture can be painful and may lead to an increase in patients' anxiety. Bruising and haematomas are not unknown and are unpleasant. For the house physician sampling is time consuming and can result in needle stick injury if due care is not taken.

We therefore aimed to determine whether arterial blood gas estimation was necessary in all patients presenting with acute severe asthma or whether oxygen saturation $\left(\mathrm{SaO}_{2}\right)$ as measured by pulse oximetry was a safe and reliable alternative in predicting those in respiratory failure and therefore in need of more intensive management. We also aimed to determine the $\mathrm{SaO}_{2}$ value below which arterial gases should be taken for the safe management of asthma.

\section{Methods}

Arterial blood gas tensions were measured using the Coral Pulsator single use heparinised arterial blood sampling system and a Radiometer ABL30 acid-base analyser and oxygen saturation via an ear or finger probe ${ }^{4}$ attached to an Ohmeda Biox 3740 pulse oximeter in 89 consecutive admissions between July 1992 and April 1993 to our respiratory unit with acute severe asthma. Both measurements were made as part of the initial clinical assessment. No attempt was made to make measurements with the patients breathing air or a standard concentration of oxygen since this study was undertaken on patients being managed according to recommended guidelines. ${ }^{5}$

As markers of the severity of asthma on admission and the degree of reversibility, peak expiratory flow (PEF) on admission was expressed as a percentage of the patient's best PEF value previously recorded out of hospital or, when these data were not available, their maximum PEF value prior to discharge.

\section{Results}

The age range and smoking history of the 89 patients are shown in table 1 . The differences in age and in smoking history between those patients with $\mathrm{SaO}_{2}$ above and below $92 \%$ were not significant. Oxygen saturation ranged between $84 \%$ and $99 \%$ (median 95\%); 17 patients had $\mathrm{SaO}_{2}<92 \%$ (table 1). Eight of the 89 patients were in respiratory failure $\left(\mathrm{PaO}_{2}\right.$ $<8 \mathrm{kPa}$ and/or $\mathrm{PaCO}_{2}>6 \mathrm{kPa}$ ) (table 2). Five of the 17 patients with $\mathrm{SaO}_{2}<92 \%$ had respiratory failure. Of the 72 patients with $\mathrm{SaO}_{2}>92 \%$ three $(4 \cdot 2 \%)$ had arterial gas tensions indicating

Table 1 Demographic details of patients

\begin{tabular}{lll}
\hline & $\begin{array}{l}\mathrm{SaO}_{2}>92 \% \\
(n=72)\end{array}$ & $\begin{array}{l}\mathrm{SaO}_{2}<92 \% \\
(n=17)\end{array}$ \\
\hline $\begin{array}{l}\text { Mean (range) age } \\
\text { (years) }\end{array}$ & $32(13-79)$ & $43(16-65)$ \\
$\begin{array}{l}\text { Smokers (past and } \\
\text { present) }\end{array}$ & $21(29 \%)$ & $8(47 \%)$ \\
\hline
\end{tabular}

$\mathrm{SaO}_{2}=$ oxygen saturation. 
Table 2 Arterial gases and oximetry of patients in respiratory failure

\begin{tabular}{llcl}
\hline Patient no. & $\mathrm{SaO}_{2}(\%)$ & $\mathrm{PaO}_{2}(\mathrm{kPa})$ & $\mathrm{PaCO}_{2}(\mathrm{kPa})$ \\
\hline 1 & 87 & $7 \cdot 4$ & $4 \cdot 5$ \\
2 & 89 & $7 \cdot 4$ & 5 \\
3 & 90 & $6 \cdot 6$ & $4 \cdot 7$ \\
4 & 91 & $7 \cdot 7$ & $4 \cdot 5$ \\
5 & 91 & $7 \cdot 9$ & $5 \cdot 5$ \\
6 & 94 & $7 \cdot 4$ & $4 \cdot 1$ \\
7 & 95 & $10 \cdot 2$ & $6 \cdot 1$ \\
8 & 96 & $7 \cdot 9$ & $5 \cdot 1$ \\
\hline
\end{tabular}

$\mathrm{SaO}_{2}=$ oxygen saturation, $\mathrm{PaO}_{2}=$ arterial oxygen tension, $\mathrm{PaCO}_{2}=$ arterial carbon dioxide tension

Table 3 Summary of oximetry readings

\begin{tabular}{lll}
\hline & No. of patients & $\begin{array}{l}\text { No. of patients in } \\
\text { respiratory failure }\end{array}$ \\
\hline $\mathrm{SaO}_{2}>92 \%$ & $72(80 \cdot 9 \%)$ & $3(4 \cdot 2 \%)$ \\
$\mathrm{SaO}_{2}>90 \%$ & $82(92 \%)$ & $6(7 \cdot 3 \%)$ \\
Total & $89(100 \%)$ & $8(9 \cdot 0 \%)$ \\
\hline
\end{tabular}

$\mathrm{SaO}_{2}=$ oxygen saturation.

Table 4 Mean (range) clinical status of patients with respect to oxygen saturation $\left(\mathrm{SaO}_{2}\right)$ and arterial blood gas tensions $(\mathrm{ABG})$

\begin{tabular}{|c|c|c|c|c|}
\hline & $\mathrm{SaO}_{2}>92 \%$ & $\mathrm{SaO}_{2}<92 \%$ & $\begin{array}{l}A B G \text { not in } \\
\text { respiratory } \\
\text { failure }\end{array}$ & $\begin{array}{l}A B G \text { in } \\
\text { respiratory } \\
\text { failure }\end{array}$ \\
\hline $\begin{array}{l}\text { Heart rate }(/ \min ) \\
\text { Systolic paradox } \\
\text { (mm Hg) }\end{array}$ & $\begin{array}{l}96(68-150) \\
4(0-30)\end{array}$ & $\begin{array}{l}100(68-140) \\
7(0-33)\end{array}$ & $\begin{array}{l}97(68-150) \\
6(0-30)\end{array}$ & $\begin{array}{l}95(68-124) \\
9(0-33)\end{array}$ \\
\hline $\begin{array}{l}\text { Respiratory rate (/min) } \\
\text { Admission PEF (1/min) } \\
\text { *Degree of reversibility } \\
(\%)\end{array}$ & $\begin{array}{l}25(15-36) \\
230(60-480) \\
56(19-95)\end{array}$ & $\begin{array}{l}27(20-36) \\
150(60-340) \\
32(17-45)\end{array}$ & $\begin{array}{l}25(15-36) \\
220(60-480) \\
54(17-95)\end{array}$ & $\begin{array}{l}25(20-30) \\
140(75-210) \\
37(25-42)\end{array}$ \\
\hline
\end{tabular}

* Admission PEF/best PEF (\%).

\section{Discussion}

These data suggest that oxygen saturation, measured by pulse oximetry, can give an indication of which patients presenting with acute severe asthma are likely to be in respiratory failure and therefore in need of more intensive management. When oxygen saturation is $92 \%$ or greater respiratory failure is unlikely. Blood gas tensions should be measured in patients with acute severe asthma whose $\mathrm{SaO}_{2}$ is below $92 \%$ on admission regardless of their inspired oxygen concentration. Arterial sampling is not required in patients with an $\mathrm{SaO}_{2}$ of $92 \%$ or higher unless their condition does not improve objectively or deteriorates, remembering that $\mathrm{SaO}_{2}$ does not assess alveolar ventilation. ${ }^{6}$ All medical wards to which patients with asthma are admitted should be equipped with a pulse oximeter. $^{3}$

This study was performed in a busy acute respiratory medical unit on asthmatic patients admitted as emergencies. Inspired oxygen concentration was not recorded in $30 \%$ of patients when $\mathrm{SaO}_{2}$ and arterial gas tensions were measured. This is a potential weakness in the study, but is likely to approximate or even exceed routine clinical practice. Furthermore, even when recorded it may be difficult to state precisely the inspired oxygen percentage at the moment of blood gas or $\mathrm{SaO}_{2}$ measurement. Patients may be having, or have just completed, nebulised medication driven by higher concentrations of oxygen. Inspired oxygen concentrations may have just been changed or masks may not fit properly. Although most of our measurements were taken when the patient was recorded as breathing air, any further interpretation of the data may be potentially misleading. ${ }^{7}$ Other factors which need to be considered when interpreting oxygen saturation measurements include a history of recent smoking and anaemia. ${ }^{8}$ Each will tend to give falsely high results. ${ }^{9}$ These data, obtained from patients shortly after their admission, suggest that an $\mathrm{SaO}_{2}>92 \%$ is a clinically useful result whatever the percentage of inspired oxygen.

Admission PEF expressed as a percentage of the patient's best PEF value was lower in those patients with an $\mathrm{SaO}_{2}<92 \%$ and also in those with respiratory failure. This supports the use in the British guidelines ${ }^{35}$ of a PEF value of less than $33 \%$ predicted or best to indicate a very severe life threatening attack. Heart and respiratory rates and the degree of paradox ${ }^{10}$ appear to correlate less well with severity of asthma as measured by pulse oximetry and blood gas tensions.

During the study period no patients required ventilation and recordings from such a group would have added strength to the study. The fact that two patients had $\mathrm{SaO}_{2}$ values $>92 \%$ (94\% and $96 \%$ ) with $\mathrm{PaO}_{2}$ values $<8 \mathrm{kPa}$ was worrying but emphasises the need for continual reassessment in all patients admitted with asthma, no matter what the initial $\mathrm{SaO}_{2}$ or $\mathrm{PaO}_{2}$. When patients fail to improve according to objective assessment of peak flow and $\mathrm{SaO}_{2}$ then arterial gas tensions should be measured or repeated. 
1 McFadden ER, Lyons HA. Arterial blood gas tension in asthma. $N$ Engl $¥$ Med 1968;278:1027-32.

2 Rebuck AS, Read J. Assessment and management of severe asthma. Am f Med 1971;51:788-98.

3 British Thoracic Society. Guidelines on the management of asthma. Thorax 1993;48:S1-24.

4 Clayton DG, Webb RK, Ralston AC, Duthie D, Runciman WB. Pulse oximeter probes. Anaesthesia 1991;46: $260-5$

5 Statement by the British Thoracic Society, Research Unit of the Royal College of Physicians of London, King's Fund Centre, National Asthma Campaign. Guidelines for the manament of asthma in adults: II - Acute severe asthma. BMf 1990;301:797-800.
6 Hutton $P$, Clutton-Brock $T$. The benefits and pitfalls in pulse oximetry. BMf 1993;307:457-8.

7 Rudolf M, Turner JA McM, Harrison BDW, Riordan JF, Saunders KB. Changes in arterial blood gases during and after a period of oxygen breathing in patients with chronic hypercapnic respiratory failure and in patients with asthma. Clin Sci Mol Med 1979;59:389-96.

8 West J. Respiratory physiology - the essentials. 4th edn. Baltimore: Williams and Wilkins, 1990: 69-85.

9 Ralston AC, Webb RK, Runciman WB. Potential errors in pulse oximetry. Anaesthesia 1991;46:202-6.

10 Pearson MG, Spence DPS, Ryland I, Harrison BDW. Value of pulsus paradoxus in assessing acute severe asthma. BMF 1993;307:659.

\title{
Non-tuberculous pulmonary infections in Scotland: a cluster in Lothian?
}

\author{
Friederike G E Böllert, Brian Watt, Andrew P Greening, Graham K Crompton
}

Respiratory Medicine Unit, Western General Hospital, Edinburgh EH4 2XU, UK

F G E Böllert

A P Greening

G K Crompton

Scottish Mycobacteria Reference Laboratory, Edinburgh EH10 5SB, UK

B Watt

Reprint requests to: Dr F G E Böllert.

Received 29 June 1994 Returned to authors 5 September 1994 Revised version received 17 October 1994 Accepted for publication 10 November 1994

\begin{abstract}
Background - A retrospective study was carried out to confirm the clinical impression that, in Lothian, non-tuberculous mycobacterial infections are as common as pulmonary tuberculosis.

Methods - All pulmonary isolates of Mycobacterium tuberculosis/bovis and nontuberculous mycobacteria in Scotland from April 1990 to March 1993, and the notes of all patients with $M$ malmoense isolates in Lothian, were reviewed. Information on mycobacterial culture procedures in Scottish laboratories was obtained as part of an audit project.

Results - Of all pulmonary isolates of mycobacteria in Lothian 53\% (108/205) were non-tuberculous strains compared with $18 \%(140 / 800)$ for Scotland outside Lothian. Although comparable in population size and laboratory techniques, Lothian (108) had almost twice as many isolates of non-tuberculous mycobacteria as Glasgow (56), but the proportions of $M$ malmoense and $M$ avium intracellulare complex were similar in both areas. Of 41 patients with $M$ malmoense isolates in Lothian 30 (75\%) had clinically significant lung disease; only one was HIV positive. Conclusions - Non-tuberculous mycobacteria pose an increasing clinical problem in Scotland as a cause of pulmonary disease. There is a cluster of cases with $M$ malmoense infection in Lothian which cannot be attributed to the high local prevalence of HIV.

(Thorax 1995;50:188-190)
\end{abstract}

Keywords: non-tuberculous mycobacteria, Mycobacterium malmoense, Lothian.

A review of all pulmonary mycobacterial isolates in Scotland over three years revealed that almost half of all Scottish isolates of $\mathrm{Myco-}$ bacterium malmoense were from patients in Lothian. $M$ malmoense was first described as a pulmonary pathogen in $1977^{1}$ but has since been reported in increasing frequency in Europe. $^{2-7}$ The organism has only rarely been isolated in the USA and from immunocompromised patients. $^{8-10}$ This study attempted to determine whether the clustering of patients with $M$ malmoense in Lothian was genuine or due to the use of different laboratory methods.

\section{Methods}

The names of all patients in Scotland with positive pulmonary isolates (sputum, bronchial washings, lung tissue, pleural fluid, and biopsies) of $M$ tuberculosis, $M$ bovis, and nontuberculous mycobacteria during the period April 1990 to March 1993 were obtained from the Scottish Mycobacteria Reference Laboratory in Edinburgh. Age, sex, postcode, HIV status, and details of antimycobacterial treatment for these patients were collected from general practitioners and consultant colleagues. Information on mycobacterial culture procedures in Scottish bacteriology laboratories was available through an audit project of the Reference Laboratory. In order to assess possible clustering of cases within Lothian we related the number of patients with $M$ malmoense strains to their postcode districts and the population figure of that area based on the 1991 census.

\section{Results}

All data concerning positive mycobacterial cultures represent pulmonary samples of patients which were received by the laboratories during the period April 1990 to March 1993. 